\title{
Static, dynamic balance and functional performance in subjects with and without plantar fasciitis
}

\author{
Equilíbrio estático, dinâmico e desempenho funcional \\ em indivíduos com e sem fasciíte plantar
}

Geiseane Aguiar Gonçalves, Danilo Harudy Kamonseki, Bruna Reclusa Martinez,
Maythe Amaral Nascimento, Império Lombardi Junior, Liu Chiao Yi

Universidade Federal de São Paulo (UNIFESP), Santos, SP, Brazil

\begin{abstract}
Introduction: Plantar fasciitis (PF) is characterized by non-inflammatory degeneration and pain under the heel, and is one of the most common foot complaints. The compensations and adjustments made to decrease the discomfort caused by the disease are clinical findings and can be a factor that contributes to impaired balance and decreased functional performance. Objective: To compare functional performance as well as static and dynamic balance among subjects with and without PF. Methods: The sample consisted of 124 subjects of both sexes aged 20-60 years. Participants were divided into two groups: a bilateral PF group (PFG; $\mathrm{n}=62$ ) and a control group (CG, $\mathrm{n}=62$ ). The following outcomes were analyzed: static and dynamic balance (using functional tests) and functional performance (using a questionnaire). We used Student's $t$ test for independent samples to compare variables between the groups. The alpha error was set at 0.05 . Results: Subjects with PF showed greater impairment in their overall dynamic balance performance $(\mathrm{p}<$ $0.001)$ than the control group, except for left posteromedial movement $(p=0.19)$. The CG showed showed better functional performance $(\mathrm{p}<0.001)$ than the PF group. There was no difference between groups for the variable static balance on stable $(p=0.160)$ and unstable surfaces $(p=0.085)$. Conclusion: Subjects with PF displayed smaller reach distances in the overall Star Excursion Balance Test (SEBT), demonstrating a deficit in dynamic balance and functional performance when compared with healthy subjects.
\end{abstract}

Keywords: Plantar Fasciitis. Balance. Foot. Functionality.

GAG: Master Student, e-mail: geiseane.agoncalves@gmail.com

DHK: MS, e-mail: fisiot.danilo@hotmail.com

BRM: Master Student, e-mail: brunareclusa@gmail.com

MAN: Master Student, e-mail: maythe.nas@gmail.com

ILJ: PhD, e-mail: imperiolombardi@ig.com.br

LCY: PhD, e-mail: liuchiaoyi@yahoo.com.br 


\section{Resumo}

Introdução: A fasciíte plantar (FP) caracteriza-se por uma degeneração não inflamatória e dor na parte inferior do calcanhar, sendo uma das queixas mais comuns na região do pé. As compensações e as adaptações para diminuir o desconforto da doença é um achado clínico e atua como um fator que pode contribuir para o comprometimento no equilíbrio e no desempenho funcional. Objetivo: comparar os equilíbrios estático, dinâmico e o desempenho funcional entre indivíduos com e sem a FP. Métodos: participaram da pesquisa 124 voluntários distribuídos em dois grupos: grupo fasciíte plantar bilateral (GFP; $n=62$ ) e grupo controle (GC; $n$ = 62) de ambos os sexos, na faixa etária de 20 a 60 anos. Os desfechos analisados foram o equilíbrio estático, equilíbrio dinâmico por meio dos testes funcionais e o desempenho funcional por um questionário. Os resultados foram analisados utilizando o teste $t$ de Student de amostras independentes para comparar as variáveis entre os grupos. O erro alfa considerado foi $p<0,05$. Resultados: Indivíduos com FP apresentaram maior comprometimento durante o teste de equilíbrio dinâmico total $(p<0,001)$, exceto no movimento póstero-medial esquerdo $(p=0,19)$. O GC apresentou melhor desempenho funcional $(p<0,001)$ e não houve diferença entre os grupos para a variável equilíbrio estático nas superfícies estável $(p=0,160)$ e instável $(p=0,085)$. Conclusão: Indivíduos com FP obtiveram menores alcances no SEBT total, apresentando déficit de equilíbrio dinâmico e comprometimento no desempenho funcional quando comparados com os participantes saudáveis.

Palavras-chave: Fasciíte Plantar. Equilíbrio. Pé. Funcionalidade.

\section{Introduction}

Plantar fasciitis (PF) is one of the most common foot pain complaints (1). It is a major orthopedic injury that affects about $10 \%$ of the world's population at least once in life $(2,3)$. PF is characterized by a non-inflammatory degeneration and pain under the heel and along the medial side of the plantar fascia $(3,4)$. It occurs as a result of repetitive microtrauma at the origin of the medial tuberosity of the calcaneus $(5,6)$. Its etiology is multifactorial and includes anatomical and biomechanical factors (7).

The feet are the only body segments that come into direct contact with the ground surface, especially during weight bearing and gait. When their anatomical and sensorial structure is intact, with no joint or soft tissue changes, they contribute to the maintenance of postural stability. Because PF is a disease that affects the feet, it can impair balance due to the discomfort felt in the plantar fascia $(8,9)$.

Balance can be statically defined as the ability to maintain upright posture while keeping the center of gravity (CG) within the base of support and with minimal fluctuation. It is dynamically defined as the ability to perform tasks while maintaining a stable body position and without changing the base of support $(10,11)$. An individual's ability to maintain proper posture during imbalance situations depends on his/ her physical integrity (12).
Individuals with PF use compensatory strategies to decrease the discomfort felt at the origin of the plantar fascia $(13,14)$. They usually adopt antalgic gait pattern whereby they decrease the time of heel contact with the ground, by increasing support on the lateral and anteior face of the foot (15). These compensations change joint position sense and muscle activations, causing body oscillations that make it difficult to maintain an upright posture within the base of support. This can impair the static and dynamic balances $(2,16)$.

After a long period of disease, the adaptations made by the body influence the biomechanical function of the lower limbs (LL) and compensations become automatic, affecting the functional performance of individuals (17) and making it difficult for them to perform daily activities such as household chores, work tasks, leisure interest and sports activities (18).

However, despite the evidence that musculoskeletal and sensory problems in the foot adversely affect the tissues around the injury and become an ascending change that impairs postural stability and the performance of daily activities (19), we found no studies assessing static and dynamic balance in individuals with problems arising from PF. It was therefore found important to investigate the influence of PF on balance, comparing PF patients with healthy people, in order to identify potential differences in functional tests and then propose additional contributions to the prevention, diagnosis and treatment of this disease. 
This study aimed to compare functional performance and static and dynamic balance between subjects with PF and controls. Our hypothesis is that individuals with the PF show greater impairment in functional performance and static and dynamic balance than individuals without $\mathrm{PF}$.

\section{Methods}

\section{Casuistry}

We conducted a cross-sectional case-control study of 124 patients of both sexes, aged 20-60 years, and who completed the entire assessment battery. Participants were divided into two groups: a plantar fasciitis group (PFG; $\mathrm{n}=62$ ) and a control group (CG, $\mathrm{n}=62$ ). All participants in the CG were matched for age, sex and body mass index (BMI) with subjects in the PFG (Figure 1). Recruitment consisted of verbal invitation as well as print and digital advertisements. The PFG was assessed in the Federal University of São Paulo and the CG was assessed at basic health units in the city of Santos, SP, Brazil. This study was approved by the Research Ethics Committee, (Protocol Number 186.766/13).

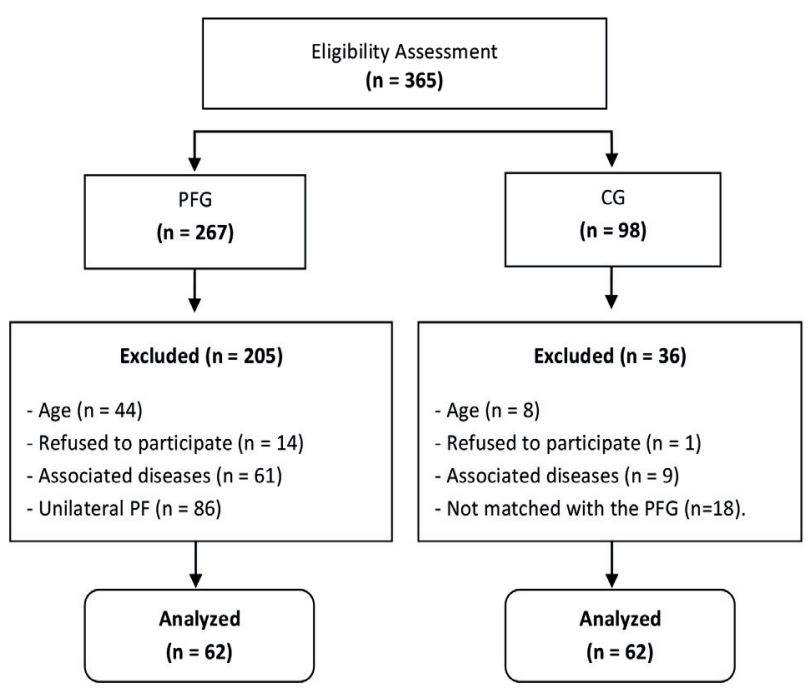

Figure 1 - Sample selection flowchart.

\section{Inclusion Criteria}

Diagnosis of bilateral FP. Volunteers also had to meet the following criteria: localized pain in the medial aspect of the calcaneus when taking first steps of the day; decrease in symptoms after low-intensity walking; and increased pain in the evening after daily activities. Patients also had to meet at least one of the following criteria: pain after standing for a long time; and pain upon weight bearing after a period of nonweight bearing (in a seated or lying position) $(4,20)$. Volunteers in the control group should have no foot pain symptoms.

\section{Exclusion Criteria}

Volunteers were excluded if they had a history of fractures or surgery in the lower limbs; discrepancy in length of the lower extremities greater than or equal to $1 \mathrm{~cm}$; trauma and orthopedic disease in the lower limbs (such as tarsal tunnel syndrome, tendinopathy of the Achilles tendon and metatarsalgia) in the last six months; systemic disease that may predispose to heel pain (such as diabetes mellitus, fibromyalgia and neurological disease).

\section{Procedures}

All participants selected for the study were submitted to a 45-minute assessment protocol. For all study subjects, we first obtained the following information using a general questionnaire: age, gender, stature, body mass, length of the lower limbs, leg dominance, duration of injury (months), level of pain and functional performance. Next, we performed the functional test.

\section{a) Pain Assessment}

Pain was measured by the Visual Analogue Scale (VAS) consisting of a horizontally orientated 10 $\mathrm{cm}$ line anchored at opposite ends by the descriptors "No Pain" (0) and "Worst Pain" (10). Participants indicated the pain they felt at the time of assessment. The VAS is valid and reliable (21) and has already been used in patients with PF.

\section{b) Functional Performance Assessment}

The Foot and Ankle Outcome Score (FAOS) is a questionnaire intended to evaluate symptoms and functional limitations related to the foot and ankle. It is divided into five subscales: (a) pain; (b) symptoms (stiffness, swelling, crepitus and limitation of movement); (c) function in activities of daily living (ADL); (d) function in sports (Sports); and (e) quality of life (QoL). Each subscale is normalized so that scores of 0 and 100 represent extreme symptoms and no symptoms, respectively. The intra-rater (ICC $=1.0$ ) and inter-rater reliability (ICC $=0.9$ ) indicated that the FAOS is an excellent measurement tool for assessing functional performance (22). 
c) Foot Posture Assessment

The Foot Posture Index (FPI) is a clinical tool designed to provide a multidimenssional and multiplanar foot posture assessment. During the test, the volunteers were told to carry out stationary gait for five seconds. Then they were asked to stand still in bipedal stance, without tilting the trunk forward, keeping the upper limbs alongside the body, and looking horizontally forward (23).

The FPI involved the rating of six items: palpation of the talar head, observation of supra/infra malleolar curvature, inversion/eversion of the calcaneus, medial prominence of the talo-navicular joint, congruence of the medial arch, and abduction/adduction of the forefoot on rearfoot. Each item is scored between -2 and +2 . Therefore, total scores may range from -12 to +12 . Scores are classified as follows: 0 to 5 (neutral); -1 to -12 (supinated) and 6 to 12 (pronated) (23).

d) Dynamic Balance Assessment

Dynamic balance of the lower limb was assessed using the Star Excursion Balance Test (SEBT) (24) described by Plisky et al. (10), which showed excellent intra and inter-rater reliability (ICC $=0.91$; ICC $=0.99$ ). The subjects received visual demonstrations and verbal instructions prior to starting the test. Then they were asked to stand in unipedal support in the middle of three lines (two rear lines making a $90^{\circ}$ angle between one another and a $135^{\circ}$ angle in relation to the forward line) and then move the contralaral limb seven times in each direction. The last reach distance measured was used in the analysis. In order to avoid the influence of the length of the lower limbs, the total SEBT score was calculated by dividing the sum of the largest anterior (ANT), posteromedial (PM) and posterolateral (PM) reach distance scores by three times the length of the lower limb (LL) and multiplying the result by $100[($ ANT + PL + PM / 3xLL) x100] (24).

\section{e) Static Balance Assessment}

The static balance was assessed using the Balance Error Score System (BESS), which proved to be a reliable tool with high inter (ICC $=0.93$ ) and intra-rater reliability $(I C C=0.98)(25)$. Subjects were instructed to remain as motionless as possible for 20 seconds while keeping their eyes closed and hands on their hips, and change to the following positions: bipedal support, unipedal support with the contralateral knee flexed to $90^{\circ}$, and Tandem position. The assessment is carried out on a stable, even ground surface and on an unstable surface on a foam cushion ( $56 \mathrm{~cm}$ long, $35 \mathrm{~cm}$ wide, $14 \mathrm{~cm}$ high, and density 100). Thus, measurements were made at a total of six positions on each surface (11).

The score is calculated in accordance with the mistakes made during the test. Each of the following was considered to be a mistake/error: opening eyes; moving hands away from the hips; allowing the contralateral limb to touch the ground; tripping or falling; lifting the forefoot or heel; moving the hip into more than 30 degrees of flexion or abduction; and remaining out of the testing position for more than five seconds (25). The test was filmed so that the results could be analyzed later. Mistakes are scored from 0-10 points for each position. The sum of points for all postures can reach a maximum of 60 points. The higher the score, the worse the static balance (11).

Intra-rater reliability of the Functional Tests

Intra-rater reliability of the SEBT, BESS and PFI was tested on 22 volunteers with no history of pain or injury to the lower limbs. All functional tests were administered with an interval of one week between the first and the second assessment by the same rater. We used the intraclass correlation coefficient (ICC, 3.1) to identify the correlation between the two measures (26). The FPI, overall SEBT and BESS were found to have excellent reliability, with ICC values of $0.99 ; 0.99$ and 0.95 , respectively.

\section{Data Analysis}

Results were expressed as mean and standard deviation for continuous variables, and as frequencies and percentages for categorical variables. Normality and homoscedasticity were confirmed with the KolmogorovSmirnov and Levene tests, respectively.

We used Student's $t$ test for independent samples to compare the following variables: functional performance (FAOS), dynamic balance (SEBT) and static balance (BESS). The alpha error was set at 0.05 (26).

\section{Results}

Table 1 shows the anthropometric and demographic data of patients with PF and controls. It also depicts 
data on handedness, pain, and foot posture and disease duration.

Of note, both groups are homogeneous with respect to anthropometric and demographic variables, handedness and foot posture $(\mathrm{p}>0.05)$.

Table 1 - Means, standard deviation and frequency of anthropometric and demographic variables, handedness, pain, foot posture and disease duration in the PFG and CG

\begin{tabular}{|c|c|c|}
\hline \multirow{2}{*}{ Variables } & \multicolumn{2}{|c|}{ Groups } \\
\hline & PFG & CG \\
\hline Height, m (mean \pm SD) & $1.62 \pm 0.7$ & $1.59 \pm 0.8$ \\
\hline Body mass, $\mathrm{kg}$ (mean $\pm \mathrm{SD}$ ) & $76.4 \pm 11.4$ & $73.8 \pm 11.8$ \\
\hline BMI, kg/m² (mean \pm SD) & $29.6 \pm 4.6$ & $28.4 \pm 4.5$ \\
\hline Age, years (mean $\pm S D$ ) & $44.5 \pm 12.0$ & $44.7 \pm 12.4$ \\
\hline Gender, female; $\mathrm{n}(\%)$ & $57 \pm 92$ & $57 \pm 92$ \\
\hline \multicolumn{3}{|l|}{ Dominant leg } \\
\hline Right; n (\%) & $54(87)$ & $61(98)$ \\
\hline Left; n (\%) & $8(13)$ & $1(2)$ \\
\hline \multicolumn{3}{|l|}{ Pain - VAS } \\
\hline Right, cm (mean \pm SD) & $3.4 \pm 2.8$ & NA \\
\hline Left, cm (mean \pm SD) & $3.4 \pm 2.9$ & NA \\
\hline \multicolumn{3}{|l|}{ Foot posture - FPI } \\
\hline \multicolumn{3}{|l|}{ Right; ( $n=124$ feet) } \\
\hline Pronated; $\mathrm{n}$ & 27 & 30 \\
\hline Supinated; $\mathrm{n}$ & 18 & 11 \\
\hline Neutral; n & 17 & 21 \\
\hline \multicolumn{3}{|l|}{ Left; $(n=124$ feet) } \\
\hline Pronated; $n$ & 26 & 32 \\
\hline Supinated; $\mathrm{n}$ & 20 & 11 \\
\hline Neutral; $\mathrm{n}$ & 16 & 19 \\
\hline $\begin{array}{l}\text { Duration of disease, months } \\
\text { (mean } \pm S D)\end{array}$ & $21.4 \pm 20.6$ & NA \\
\hline
\end{tabular}

Note: m, meters; kg, kilogram; PFG, Plantar Fasciitis Group; CG, Control Group; BMI, body mass index; VAS, Visual Analog Scale; FPI, Foot Posture Index; NA, not applicable. Continuous variables are expressed as mean \pm standard deviation. Categorical variables are expressed as frequency and percentage (\%); * significance level set at $p<0.05$.
In Table 2 we can see that there was a significant difference between groups for the variables functional performance (FAOS) and dynamic balance (SEBT), except with regard to the left posteromedial reach distance $(\mathrm{p}=0.193)$.

There were no differences between the PFG and the CG for the variable of stable $(p=0.160)$ and unstable $(p=0.085)$ static balance (BESS score).

Table 2 - Between-groups comparison for the variables, BESS, SEBT and FAOS

\begin{tabular}{|c|c|c|c|c|}
\hline Variables & $\begin{array}{c}\text { PFG } \\
\text { Mean } \pm \text { SD }\end{array}$ & $\begin{array}{c}\text { CG } \\
\text { Mean } \pm S D\end{array}$ & Difference & $p$-value \\
\hline $\begin{array}{c}\text { BESS } \\
\text { (Stable) }\end{array}$ & $20.5 \pm 10.1$ & $17.9 \pm 10.9$ & -2.62 & 0.160 \\
\hline $\begin{array}{c}\text { BESS } \\
\text { (Unstable) }\end{array}$ & $28.0 \pm 9.0$ & $25.3 \pm 10.7$ & -2.75 & 0.085 \\
\hline $\begin{array}{c}\text { SEBT - } \mathrm{R} \\
\text { (Anterior reach) }\end{array}$ & $54.9 \pm 7.3$ & $58.8 \pm 8.7$ & 4.12 & $0.005^{*}$ \\
\hline $\begin{array}{c}\text { SEBT- L } \\
\text { (Anterior reach) }\end{array}$ & $57.0 \pm 8.1$ & $61.3 \pm 7.2$ & 4.58 & 0.004 * \\
\hline $\begin{array}{c}\text { SEBT - R } \\
\text { (Posteromedial } \\
\text { reach) }\end{array}$ & $81.2 \pm 9.1$ & $86.8 \pm 9.8$ & 5.59 & 0.002 * \\
\hline $\begin{array}{c}\text { SEBT - L } \\
\text { (Posteromedial } \\
\text { reach) }\end{array}$ & $81.8 \pm 9.8$ & $84.2 \pm 10.0$ & 2.42 & 0.193 \\
\hline $\begin{array}{c}\text { SEBT - R } \\
\text { (Posterolateral } \\
\text { reach) }\end{array}$ & $63.1 \pm 13.8$ & $69.2 \pm 12.8$ & 6.35 & 0.015 * \\
\hline $\begin{array}{c}\text { SEBT - L } \\
\text { (Posterolateral } \\
\text { reach) }\end{array}$ & $64.5 \pm 13.8$ & $73.8 \pm 12.2$ & 9.62 & 0.001 * \\
\hline $\begin{array}{c}\text { SEBT - R } \\
\text { (Total) }\end{array}$ & $66.4 \pm 8.5$ & $71.6 \pm 8.7$ & 5.36 & 0.001 * \\
\hline $\begin{array}{c}\text { SEBT - L } \\
\text { (Total) }\end{array}$ & $67.8 \pm 9.1$ & $73.1 \pm 8.5$ & 5.53 & 0.002 * \\
\hline $\begin{array}{c}\text { FAOS - R } \\
\text { (Pain) }\end{array}$ & $53.0 \pm 18.6$ & $100.0 \pm 0$ & 46.95 & 0.001 * \\
\hline $\begin{array}{c}\text { FAOS - L } \\
\text { (Pain) }\end{array}$ & $53.9 \pm 19.2$ & $100.0 \pm 0$ & 46.01 & 0.001 * \\
\hline
\end{tabular}




\begin{tabular}{|c|c|c|c|c|}
\hline $\begin{array}{c}\text { FAOS - R } \\
\text { (Symptoms) }\end{array}$ & $83.1 \pm 13.7$ & $97.4 \pm 5.7$ & 14.23 & 0.001 * \\
\hline $\begin{array}{c}\text { FAOS - L } \\
\text { (Symptoms) }\end{array}$ & $82.7 \pm 13.8$ & $97.4 \pm 5.7$ & 14.64 & 0.001 * \\
\hline $\begin{array}{l}\text { FAOS - R } \\
\text { (Activities of } \\
\text { daily living) }\end{array}$ & $63.7 \pm 20.0$ & $100.0 \pm 0$ & 36.27 & 0.001 * \\
\hline $\begin{array}{l}\text { FAOS - L } \\
\text { (Activities of } \\
\text { daily living) }\end{array}$ & $64.1 \pm 20.6$ & $100.0 \pm 0$ & 35.89 & 0.001 * \\
\hline $\begin{array}{c}\text { FAOS - R } \\
\text { (Sports) }\end{array}$ & $46.5 \pm 28.0$ & $100.0 \pm 0$ & 53.47 & 0.001 * \\
\hline $\begin{array}{l}\text { FAOS - L } \\
\text { (Sports) }\end{array}$ & $47.5 \pm 28.0$ & $100.0 \pm 0$ & 52.50 & 0.001 * \\
\hline $\begin{array}{c}\text { FAOS - R } \\
\text { (Quality of life) }\end{array}$ & $30.8 \pm 22.5$ & $100.0 \pm 0$ & 69.15 & 0.001 * \\
\hline $\begin{array}{c}\text { FAOS - L } \\
\text { (Quality of life) }\end{array}$ & $30.8 \pm 22.5$ & $100.0 \pm 0$ & 69.10 & 0.001 * \\
\hline
\end{tabular}

Note: R, right; L, left; BESS, Balance Error Scoring Test; SEBT, Star Excursion Balance Test; FAOS, Foot and Ankle Outcome Score; *significance level set at $p<0.05$.

The largest SEBT reach distances and the best functional performance (FAOS) are shown in Figures 2 and 3 , respectively.

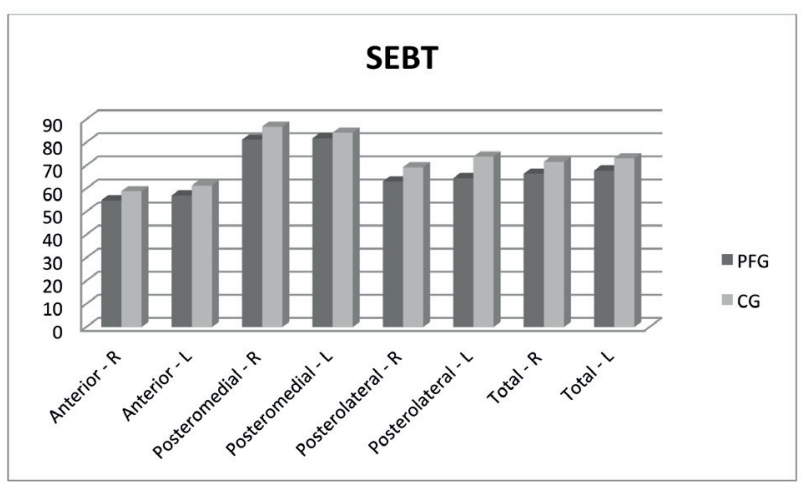

Note: PFG, Plantar Fasciitis Group; CG, Control Group; R, right; L, left; SEBT, Star Excursion Balance Test.

Figure 2 - Between-groups comparison of reach distances achieved in the dynamic balance test.

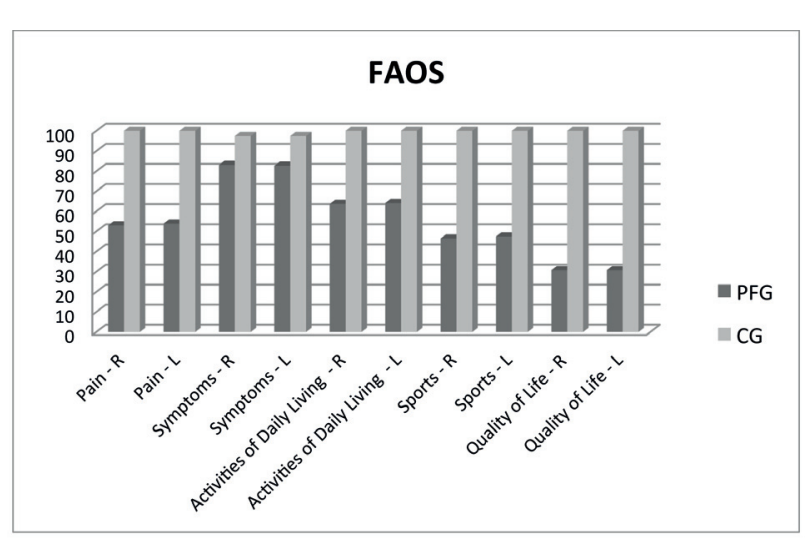

Note: Abbreviations: PFG, Plantar Fasciitis Group; CG, Control Group; R, right; L, left; FAOS, Foot and Ankle Outcome Score.

Figure 3 - Between-groups comparison of the results of the functional performance questionnaire.

\section{Discussion}

This study compared functional performance and static and dynamic balance between subjects with PF and controls. The hypothesis that the PFG would have greater dynamic balance deficit scores was confirmed, except for the left posteromedial reach.

In this study, the CG had greater reach distances in the SEBT than the PFG, possibly as a result of the increased tension in the plantar fascia, which can usually be associated with a limitation of range of motion (ROM) of the ankle joint (20). This might have adversely affected the subjects' performance in the SEBT test. During the test, the foot that remains on the ground has to perform a closed kinetic chain dorsiflexion movement $(10,24)$, and an impairment of this movement interferes with sensory information processing of the articular components of the ankle and foot, making the body's anterior displacement and the maintenance of the CG within the base of support more difficult $(12,19)$. However, the preserved flexibility of the ankle and foot is an important determinant for the maintenance of dynamic balance (9).

Another factor that may have affected the subjects' balance is plantar pain, especially when it is severe (27). This is evidenced in the performance of dynamic activities $(8,14)$. When performing a closed kinetic chain dorsiflexion movement, the foot sole remains in contact with the ground and there is an anterior displacement of the tibia (11). This leads to a stretching of the plantar fascia and, consequently, to increased tension and pain. In order to protect the musculoskeletal system and 
prevent further discomfort during the test, individuals use compensation strategies in the ankle and foot, which makes it difficult to maintain posture $(14,20)$. This may have led to differences between the groups. Nevertheless, as in this study, we did not measure pain during the SEBT, we cannot say whether there was an increase in plantar pain plant or whether the pain influenced the dynamic balance results obtained by the PFG. The level of pain of patients with PF was only assessed at rest and before the tests, and was rated as low to moderate (21).

In this study, the mean disease duration in the PFG was 21.4 months, showing that most individuals were in the chronic phase of the disease ( $>6$ th months of disease). The factor time can result in a series of faulty adaptations in the musculoskeletal system (28). From a clinical point of view, by trying to reduce the loads imposed on the hindfoot, individuals with PF tend to overload the lateral aspect of the mid and forefoot during dynamic activities, and these adjustments may increase with chronicity of the disease (5). However, we believe that this compensation mechanism may have adversely affected the maintenance of an upright posture during the SEBT test. This could explain why the PFG might have experienced difficulties in reach performance during the dynamic movement.

There was no difference between groups with regard to the SEBT scores obtained for the left posteromedial reach. We assume that both group may have had difficulties in performing this movement, because it requires a greater distance than that required for the posterolateral and anterior movements. In addition, for the right leg to perform the reach, the left leg has to be kept in contact with the ground to support and balance the body. The fact that this was the non-dominant leg for the majority of both groups may explain the difficulties experienced during dynamic balance control and the similar findings.

The hypothesis that the PFG would have greater static balance deficit scores than the CG was not confirmed in this study. The lack of differences between both groups may be explained by the fact that the BESS is performed with a minimum of body oscillations and thus the center of mass does not have to be displaced beyond the existing base of support (11). Additionally, to maintain stability during the test, the subject must use combination of hip and ankle strategies with little ROM. In this position, there is no elongation, shortening or increased tension in the plantar fascia to hinder the maintenance of the static posture. Moreover, individuals with PF only experience discomfort in the plantar surface of the foot when they stay in the standing position for long periods (29), which was not the case during the test, because it lasted approximately five minutes.

We found no studies that assessed static and dynamic balance in people with PF using functional tests. Nevertheless, most of the studies on PF analyze forms of intervention and the relationship between risk factors such as ankle ROM, overweight, age, inappropriate footwear, high-impact activities and hindfoot alignment $(20,30)$.

Functional and biomechanical assessments of the distal region of the lower limbs should be carried out to identify dysfunctions, prevent future injuries and provide references for treatment progression (29). This study also hypothesized that individuals with PF would have impaired functional performance compared to healthy controls. The results confirmed our hypothesis, because the mean scores obtained in the FAOS questionnaire by the PFG were lower than that obtained by the CG. This indicates that individuals with PF had worse functional performance than their counterparts for all variables assessed in the questionnaire, especially those related with sports and quality life. Both groups had similar scores in the subscale Symptoms (crepitus, swelling and stiffness). This is because these symptoms are not specific for PF and can manifest in individuals without the disease.

The compensations made to decrease the pain and discomfort caused by PF affect the functional performance of individuals. It is therefore important to instruct PF patients to avoid high foot impact activities, wearing shoes with low soles and little cushioning in the heel part of the sole and encourage them to wear insoles to prevent future impairments in ADL and functionality (5).

This study showed that the presence of PF adversely influenced the dynamic balance during the SEBT test. This finding shows that it is important to include a sensory-motor training in the treatment of PF. Such training aims to stimulate the intrinsic and extrinsic foot muscles, which, together with the plantar fascia, stabilize the ROM (30). This is important considering that an injured plantar fascia may lose its stabilizing function. Conversely, because of the stimulation and strengthening of the muscles, there is a consequent reduction in plantar fascia tension and pain, and an improvement in functional performance and quality of life $(20,22,30)$.

We suggest that future studies should focus on the association between dynamic balance and other risk 
factors that are related to PF, in order to verify whether the level of pain, limitation of ankle dorsiflexion ROM and foot posture can affect body balance.

We also propose that balance analyses in individuals with PF are performed using stabilometry and baropodometric analysis. We stress that the assessment tools used in this study are practical, functional and can be applied in clinical settings with excellent levels of reliability.

\section{Conclusion}

Subjects with PF displayed smaller reach distances in the overall SEBT, showing bilateral impairment of dynamic balance. Biomechanically, during the SEBT individuals have to perform a closed kinetic chain dorsiflexion movement of the ankle. A limited range of motion for this movement can affect joint sensory information. There may also be an increase in pain due to tension generated in the plantar fascia during dorsiflexion, which makes it difficult to maintain balance.

The compensations made to decrease the pain and discomfort caused by PF tend to increase with chronicity of the disease. In addition to impairing dynamic balance, they can also adversely affect the functional performance of individuals with plantar fasciitis.

The disease was not a determinant factor for static balance impairment as assessed by the BESS, during which both groups had to stay in the standing position for short periods with a minimum of body oscillations. This test therefore does not require larger ankle range of motion, thereby preventing the stretching and shortening of the plantar fascia, as well as the consequent plantar discomfort in individuals with PF.

\section{Acknowledgments}

We are grateful for the financial support granted by the Brazilian Higher Education Personnel Improvement Coordination (CAPES).

\section{References}

1. Chen H, Ho H, Ying M, Fu SN. Association Between Plantar Fascia Vascularity and Morphology and Foot Dysfunction in Individuals With Chronic Plantar Fasciitis. J Orthop Sports Phys Ther. 2013;43(10):727-34.
2. Johal B, Milner DM. Plantar fasciitis and the calcaneal spur: Fact or fiction? Foot Ankle Surg. 2012;18(1):39-41.

3. Shashua A, Flechter S, Avidan L, Ofir D, Melayev A, Kalichman A. The Effect of Additional Ankle and Midfoot Mobilizations on Plantar Fasciitis: A Randomized Controlled Trial. J Orthop Sports Phys Ther. 2015 ;45(4):265-72.

4. Renan-Ordine R, Alburquerque-Sendín F, Souza DPR, Cleland JA, Fernández-De-Las-Peñas C. Effectiveness of Myofascial Trigger Point Manual Therapy Combined With a Self-Stretching Protocol for the Management of Plantar Heel Pain: A Randomized Controlled Trial. J Orthop Sports Phys Ther. 2011;41(2):43-50.

5. Wearing SC, Smeathers JE, Urry SR, Hennig EM, AP Hills. The Pathomechanics of Plantar Fasciitis. Sports Med. 2006;36(7):585-611.

6. Jeswani T, Morlese J, McNally EG. Getting to the heel of the problem: plantar fascia lesions. Clinic Radiol. 2009;64(9):931-9.

7. Allen HR, Gross MT. Toe Flexors Strength and Passive Extension Range of Motion of the First Metatarsophalangeal Joint in Individuals With Plantar Fasciitis. J Orthop Sports Phys Ther. 2003;33(8):468-78.

8. Kleiner AFR, Schlittler DXC, Sánchez-Arias MR. O papel dos sistemas visual, vestibular, somatosensorial e auditivo para o controle postural. Rev Neurocienc. 2011;19(2):349-57.

9. Menz HB, Morris ME, Lord SR. Foot and Ankle Characteristics Associated With Impaired Balance and Functional Ability in Older People. J Gerontology. 2005;60(12):1546-52.

10. Plisky PJ, Rauh MJ, Kaminski TW, Underwood FB. Star Excursion Balance Test as a Predictor of Lower Extremity Injury in High School Basketball Players. J Orthop Sports Phys Ther. 2006;36(12):911-9.

11. Bressel E, Yonker JC, Kras J, Heath EM. Comparison of Static and Dynamic Balance in Female Collegiate Soccer, Basketball, and Gymnastics Athletes. J Athl Train. 2007;42(1):42-6.

12. Burke TN, França FJR, Meneses SRF, Pereira RMR, Marques AP. Postural control in elderly women with osteoporosis: comparison of balance, strengthening and stretching exercises. A randomized controlled Trial. Clin Rehabil. 2012;26(11):1021-31. 
13. Barbosa CM, Barros BM, Marques JF, Bellini CI, Davitt M, Paiva ME. The effect of foot orthoses on balance, foot pain and disability in elderly women with osteoporosis: a randomized clinical Trial. Rheumatology 2013; 52(3):515-22.

14. Pradels A, Pradon D, Hlavackova P, Diot B, Vuillerme N. Sensory Re-Weighting in Human Bipedal Postural Control: The Effects of Experimentally-Induced Plantar Pain. PLoS One. 2013;8(6):e65510.

15. Hamer WI. Exame Funcional dos Tecidos Moles e Tratamento por Métodos Manuais: Novas pespectivas. 1st ed. Rio de Janeiro: Guanabara Koogan; 2003.

16. Kelly LA, Kuitunen S, Racinais S, Cresswell AG. Recruitment of the plantar intrinsic foot muscles with increasing postural demand. Clin Biomech. 2012;27:46-51.

17. Khamis S, Yizhar Z. Effect of feet hyperpronation on pelvic alignment in a standing position. Gait Posture. 2007;25(1):127-34.

18. Riddle DL, Pulisic M, Pidcoe P, Johnson RE. Risk Factors for Plantar Fasciitis: A matched case-control study. J Bone Joint Surg. 2003;85(5):872-7.

19. Cote K, Brunet M, Gansneder B, Shultz S. Effects of pronated and supinated foot postures on static and dynamic postural stability. J Athl Train. 2005;40(1):41-6.

20. McPoil TG, Martin RL, Cornwall MW, Wukich DK, Irrgang JJ, Godges JJ. Heel pain- plantar fasciitis: clinical practice guidelines linked to the international classification of functioning, disability, and health from the orthopedic section of the American physical therapy association. J Orthop Sports Phys Ther. 2008;38(4):A1-A18.

21. Jensen MP, Karoly P, Braver S. The measurement of clinical pain intensity: a comparison of six methods. Pain.1986;27(1):117-26.

22. Imoto AM, Peccin MS, Rodrigues R, Mizusaki JM. Tradução e validação do questionário FAOS - Foot and Ankle Outcome Score para língua portuguesa. Acta Ortop Bras. 2009;17(4):232-5.
23. Redmond AC, Crosbie J, Ouvrier RA. Development and validation of a novel rating system for scoring standing foot posture: the foot posture index. Clin Biomech. 2006;21(1):89-98.

24. Filipa A, Byrnes R, Paterno MV, Myer GD, Hewett TE. Neuromuscular training improves performance on the star excursion balance test in young female athletes. J Orthop Sports Phys Ther. 2010;40(9):551-8.

25. McLeod TCV, Perrin DH, Guskiewicz KM, Shultz SJ, Diamond R, Gansneder BM. Serial administration of clinical concussion assessments and learning effects in healthy young athletes. Clin J Sport Med. 2004;14(5):287-95.

26. Callegari-Jacques SM. Bioestatística: princípios e aplicações. Porto Alegre (Brazil): Artmed; 2003.

27. Rosenbaum AJ, DiPreta JA, Misener D. Plantar heel pain. Med Clin N Am. 2014;98(2):339-52.

28. Fernandes TL, Pedrinelli A, Hernandez AJ. Lesão muscular - fisiopatologia, diagnóstico, tratamento e apresentação clínica. Rev Bras Ortop. 2011;46(3):247-55.

29. Lareau CR, Sawyer GA, Wang JH, DiGiovanni CW. Plantar and medial heel pain: diagnosis and management. J Am Acad Orthop Surg. 2014;22(6):372-80.

30. Martin RL, Davenport TE, Reischl SF, McPoil TG, Matheson JW, Wukich DK, et al. Heel pain - plantar fasciitis: revision 2014. J Orthop Sports Phys Ther. 2014;44(11):A1-23.

Received in 09/30/2015

Recebido em 30/09/2015

Approved in 12/16/2015

Aprovado em 16/12/2015 
